УДК 811.161 .1

DOI 10.18413/2712-7451-2020-39-2-306-316

\title{
Слова «стыд», «срам» и «позор» в говорах Архангельского региона: на пересечении значений
}

\author{
Яковлева (Редько) Н.А. \\ Военная академия Генерального штаба ВС РФ, \\ Россия, 119571, г. Москва, пр-т Вернадского, д. 100 \\ E-mail: nataliaredko@rambler.ru
}

\begin{abstract}
Аннотация. На материале бумажной картотеки и электронной базы данных «Архангельского областного словаря» проведен лексико-семантический анализ слов стыд, позор и срам, а также предикативов стыдно, позорно и срамно в говорах архангельского региона. Рассмотрена семантическая область, объединенная семами совершение неблаговидного поступка и чувство вины, охарактеризованы народные представления о морали, проявляющиеся через внутреннюю и внешнюю оценку безнравственных действий человека. В исследуемых говорах происходит четкое разграничение понятий: cmыл обозначает индивидуальное чувство, позор и срам (страм) внешнюю оценку поступков человека коллективом. В ситуации оценки человеком какого-либо безнравственного поступка (своего или чужого) предикативы стылдн, позорно и срамно (страмно), а также «зазорно» в одном из своих значений вступают в отношения синонимии.
\end{abstract}

Ключевые слова: диалектология, говоры, Архангельский областной словарь, лексикосемантический анализ, языковая картина мира.

Для цитирования: Яковлева (Редько) Н.А. 2020 Слова «стыд», «срам» и «позор» в говорах архангельского региона: на пересечении значений. Вопросы журналистики, педагогики, языкознания, 39 (2): 306-316. DOI 10.18413/2712-7451-2020-39-2-306-316

\section{The words styd, sram and pozor in Arkhangelsk dialects: semantic crossroads}

\author{
Natalya A. Yakovleva (Redko) \\ Military Academy of the General Staff of the Russian Armed Forces, \\ 100 Vernadskogo Pr-t, Moscow, 119571, Russia \\ E-mail: nataliaredko@rambler.ru
}

\begin{abstract}
Uses lexical and semantic analysis of the words styd, sram and pozor (close to shame and disgrace), their compatibility in the dialects of the Arkhangelsk region, as well as the key zone of synonymy - the predicates stydno, pozorno and sramno - on the basis of paper card files and the electronic database of the Arkhangelsk Regional Dictionary. The purpose of the research is to consider the semantic area, united by the semes 'committing an unseemly act' and 'feeling guilty', represented by the above words in a literary and dialect language; to characterize people's ideas about this aspect of morality. In the dialects under study, a clear distinction is made between concepts: styd means only individual feeling, pozor and sram (stram) - an external assessment of a person's actions by the collective. At the same time, the word pozor is ambiguous and its semantics (like in dialecticism роzогам) is more inclined to the field of hard mental experiences and physical hardships of rural life (semes 'torment', 'hard work', 'difficult living conditions'). In a situation where a person evaluates an immoral act, the predicates, being polysemantic, in one of their meanings enter into a relationship of synonymy. The results of this research can be used in courses on dialectology, lexicology, ethnolinguistics, as well as in the study of Russian mentality and the language picture of the world.
\end{abstract}


Key words: dialectology, dialects, Arkhangelsk Regional Dictionary, lexical and semantic analysis, linguistic picture of the world.

For citation: Yakovleva (Redko) N.A. 2020. The word sstyd, sram and pozor in arkhangelsk dialects: semantic crossroads. Issues in Journalism, Education, Linguistics, 39 (2): 306-316 (in Russian). DOI $10.18413 / 2712-7451-2020-39-2-306-316$

\section{Введение}

В отечественной лингвистике все более возрастает интерес к выявлению традиционных доминант русской языковой картины мира. Анализ абстрактных имен, относящихся к духовной составляющей русской ментальности, представлен в работах ведущих российских филологов: Ю.Д. Апресяна [2006], Н.Д. Арутюновой [1999]; Т.И. Вендиной [1998]; В.В. Колесова [2004]; А.А. Зализняк, И.Б. Левонтиной, А.Д. Шмелева [2012]; C.M. Толстой [2008] и многих др. Однако в подобных работах, как правило, рассматривается материал литературного языка или городского просторечия. Данные диалектного языка привлекаются учеными крайне редко (из перечисленных выше авторов на диалектном материале работают только Т.И. Вендина и С.М. Толстая), что, на наш взгляд, обедняет описание русской картины мира. Народные представления о мире хранятся главным образом в народном языке.

В настоящей статье представлены результаты лексико-семантического анализа существительных стыл, срам и позор: дан историко-лингвистический комментарий их семантики, показан ее синхронный срез в литературном языке; отражено современное функционирование этих слов, а также производных от них предикативов (cmblдн, позорно, срамно) в говорах архангельского региона.

Материалом для исследования послужили данные электронной и бумажной картотек «Архангельского областного словаря» [Архангельский областной словарь, 1980], а также личные полевые записи автора, собранные в ходе диалектологических экспедиций в Архангельскую область в 2012-2017 гг.

В ситуации оценивания человеком какого-либо своего или чужого аморального поступка проявляется тесное переплетение значений существительных стыд, срам и позор. Согласно данным «Русского ассоциативного словаря» [2002], из 103 реакций на стимул стыл преобладают: позор 16, срам 9, и позор 2, и срам 1. При этом наивные представления носителя языка о стыде тяготеют к восприятию его как индивидуального чувства признания своей вины, проявляющегося внешне, что доказывает наличие следующих реакций: краска 5, краснеть 5, красный 3, краснота 2, покраснеть 2, вгонять в краску 1. Позор же больше связан с внешней негативной оценкой одним человеком или коллективом поступка другого человека: невыносимый 2, несмываемый 2, унижение 2 , честь 2, береги честь смолоду 2, всеобщее бесчестье 1, презрение 1. Несмотря на это, среди 108 реакций на стимул позор преобладают «внутренние»: стыл 17, стылоба 1 и ужас 4, страх 2. Слово срам принадлежит разговорному пласту литературного языка и воспринимается говорящими как синоним слова позор, что доказывает наличие фразем стыл и срам и стыл $и$ позор (устроенных по принципу «внутреннее - внешнее») при отсутствии в языке выражения срам и позор.

Чтобы установить семантические сходства и различия этих слов, рассмотрим их этимологию и бытование в литературном языке, а затем сопоставим полученные результаты с данными говоров архангельского региона.

\section{Существительные стыл, позор, срам}

\section{Cmbld}

Слово cmbld восходит к общеславянскому слову studъ (stydъ), в исходном значении именовавшему «то, что заставляет сжиматься, цепенеть, коченеть» [Черных, 1999, с. 214]. 
Кроме русского, оно представлено и в других современных славянских языках: укр. стид, польск. wstyd, серб. стиिд, болг. студ [Фасмер, 2009, с. 789].

Анализируя этимологию существительного cmbld, М.В. Рукавишникова [2009, c. 124] отмечает, что первоначально и стужа, и стыд использовались для обозначения холода как явления природы, а также состояния человека. Далее развитие семантики шло «путем метонимии от “стыда наготы” через обозначение интимных действий и частей тела к пороку».

Обратим внимание, что исконностыд, связанный с пороком, семантически был близок позору. Ветхозаветное значение слова cmbld - внешний стыд, позор, «покрывающий человека в глазах других людей» [Арутюнова, 2000, с. 56].

В древнерусских памятниках слово стыл отмечено с XI века в двух значениях: 1) чувство смущения, неловкости - с великим стыдомъ вопроси, двичей стыдъ; 2) позор, бесчестье - позорства и стылда великаго [СРЯ XI-XVII вв., 2008, с. 222-223].

В дальнейшем значение слова cmыљ эволюционирует в сторону более личного чувства, хотя связь с общественным мнением остается в его семантике. Стыд предполагает взгляд извне: стылдно, когда видно, а когда не видно, то уже и не стылно.

В русском языке сформировалась синонимическая пара: стыд как проявление индивидуального чувства человека и срам как объективное отношение коллектива к человеку или его поступку. Позднее произошло устранение дуализма понятий и замещение пары cmbld - срам одним словом стыд в двух значениях: «эмоциональном» (внутренняя оценка) и «деонтическом» (внешняя оценка) [Шмелев, 2002, с. 118]. Отметим, что в просторечии и диалектах слово срам продолжает существовать.

Cmыљ в говорах архангельского региона обозначает индивидуальное чувство, возникающее при осознании несоответствия своих действий правилам поведения, которые негласно закреплены в коллективе. В экспрессивном выражении сты́́d-то како́й актуализируется субъект - носитель чувства: $A$ како́й сты́́d-то ей, она́ всё потеря́ла ${ }^{2}$. Отсутствие стыда у человека, совершающего аморальный поступок, подчеркивается с помощью двойного отрицания в словосочетании ниско́лько ни стыда́: Э́то смотре́ть позо́р! И ниско́лько ни стьлда́!

Существительное $c m ы \partial$ часто употребляется в предикативной функции в составе устойчивых сочетаний сть́́一-то како́й, за cmbld, имеющих значение «стыдно»: Пришли́ го́сти, я сё в подо́ле ката́ю - сть́́d-то како́й! Седина́ или ль́ісость - ничего́, не за сть́́ сейчác. Стыд в подобных контекстах сближается со стеснением и боязнью публичного позора, но обращен на характеристику говорящим самого себя, а не другого.

С представлениями о бесчестии, позоре связана конструкция со стыло́́ с пирого́м: A я́-то куда́ пое́ду со стыло́м с пирого́м? (о рожденном вне брака). Значение этого выражения может интерпретироваться по-разному:

a) C пирого́м - 'с новорожденным ребенком'. Метафорическая связь «человек хлеб» просматривается, например, в семантике слова новоиспечённый. Со стыло́м - 'испытывая стыд оттого, что ребенок незаконнорожденный'.

б) Со стыло́́ - 'с незаконнорожденным ребенком'. С пирого́м - 'ни с чем'. Ср. диал. 'вернуться с рыбалки или охоты без добычи' - прийти́с пирого́м, с сухарём, с ко́лобом.

Семантика стыда в говорах ярко проявляет себя в метафорической глагольной сочетаемости.

Держа́mь за стыл - 'считать постыдным': А ра́ньше рука́ го́ла - за сть́́ держа́ли (нельзя ходить в одежде с голыми руками).

Напринима́ться стыда́ - 'чувствовать угрызения совести': Tуm стыда́-то напринима́ется, да в тюрьму поса́дят, да всё.

${ }^{1}$ В говорах архангельского региона - в двух фонемных вариантах: срам и страм.

${ }^{2}$ Примеры из картотеки АОС даны в орфографии с указанием места ударения. 
Cmыl может являться внутренней составляющей (у кого-то ecmb cmbld или нет

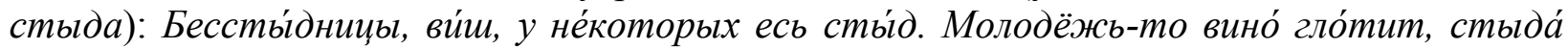
не́m. Стыд можно увидеть в глазах: У них не́mу в глаза́x cmыла́! Глаза метонимически замещают человека в экспрессивном выражении сть́́дно глази́щам: Взял де́ньги, дак не захо́dum, сть́́дно-то глази́щам. В «Словаре русских народных говоров» отмечены синонимичные словосочетания cmbldb́ до глаз 'будет очень стыдно кому-то': Чaй, cmbldbl до глаз, кто придет, в избе-ти грязи в колен. Убирайте скорее, стылыь до глаз, кто увидит. Горьк. [СРНГ, 2008, с. 112]; гла́зы лу́пятся у кого-н. 'становится стыдно': Не хочу, чтоб из-за тебя у меня глазы лупились. Смол. [СРНГ, 1970, с. 185].

В статье «О стыде и стуже» Н.Д. Арутюнова [1997, с. 59] отмечает несоответствие между этимологической соотнесенностью с холодом и реализацией в языке «жаркого» образа, основным симптомом которого является покраснение лица: раскраснеться от мороза, но покраснеть от стылда; горячий, жгучий, но не холодный, ледяной стыл. Связь стыда с внутренним сгоранием рассмотрена в статье О.П. Ермаковой [1999] «Концепты СОВЕСТЬ и СТЫД по данным языка».

В изучаемых говорах также бытует характерное для носителя литературного языка восприятие стыда как чего-то обжигающего: пламени, костра и т. п. Сгорámb co cmbldá 'испытывать сильное чувство стыда': Cpáм mbl, со cmbldá сгори́м с тобо́й. Oн ве́сь перемени́лся, ве́сь покрасне́л - э́то ведь со стыда́ сгори́шь. Стыд воспринимается говорящими как пламя, которое обжигает или даже уничтожает изнутри.

При этом в говорах отмечена восходящая к этимону концептуализация стыда как чего-то обжигающего не жаром, а холодом. Стыд похож на озноб в выражении $\mathrm{cmbl}$ беpёm кого-н. 'становится стыдно': Меня́ cmыд берёт. Неслучайно в говорах глагол брать имеет значение 'охватывать, одолевать каким-л. состоянием', чаще всего связанным с болезнью, реже - с холодом, ознобом: Гри́nп-от постоя́нно берёт, все переболе́ют гри́ппомто. Хо́лодно сего́дня, так и берёт. Ка́к я ли гре́лась, меня́ не берёт (холод).

\section{2. Позор}

Общерусское существительное позор восходит к праславянскому *zrmti (т.е. образовано от глагола зреть - 'видеть') и первоначально обозначало 'внимание' [Фасмер, 2009 , с. 303]. В одних славянских языках это значение сохранилось (в чешском, словацком, словенском), в других - претерпело значительные изменения: например, польск. роzомr - 'видимость', укр. позір - 'первый взгляд'. Однако связь с этимоном проявляется во всех славянских языках через обязательное наличие «зрителя»: например, в русском языке человек позорится, только когда его проступок или неприглядное положение увидели другие.

Еще в начале XIX в. значение общерусской лексемы в литературном языке не устоялось. В.В. Виноградов [Виноградов, 1941, с. 18] отмечал, что в языке ранних стихотворений А.С. Пушкина «позор употребляется в своем старом, церковно-славянском значении: 'зрелище'», а уже с начала 1820-х гг. поэт использует это словов значении 'постыдное, презренное положение'. Сдвиг от исконной семантики к современной происходил через промежуточное значение 'неприглядное зрелище'. В современном русском литературном языке позор - 'постыдное, унизительное для кого-л. положение, вызывающее презрение; бесчестье' [MAC, URL].

В говорах архангельского региона общерусское слово позомр сосуществует с диалектным словом позорам (позомра). Своими значениями они входят в три семантические зоны: 1) 'унизительное положение, в котором человек вызывает презрение у окружающих’, 2) 'душевная мука, мучение, беспокойство', 3) 'физические мучения, тяжелые условия жизни и труда'.

\section{Позо́р -}

(1) 'Унизительное положение, в котором человек вызывает презрение у окружающих': Я позо́ру не хоте́ла, потому́ что у все́х была́ в чести́. Данное значение наиболее ярко проявляется в несвободной предложно-падежной или глагольной сочетаемости: 
На позо́р - 'на осуждение': Бе́дны робя́тки, ой, однь́хx оста́вят. Наноси́ла на позо́р (т. е. дети будут страдать из-за поступка матери).

Брать на себя́ позо́р - 'совершать проступок, ставя тем самым себя в унизительное положение’: Не бу́ду на себя́ позо́р бра́mь!

Сде́лать позо́р - 'опозорить, поставить в унизительное положение': Не заворова́лася, сьі́ну позо́ра не сде́лала. Они́ позо́ру не сде́лали, вь́шли вза́муж за мужико́в.

Дава́ть на позо́р - 'позволять ставить кого-л. в унизительное положение': В шеся́m лет я не буду себя на позо́р дава́ть.

(1.1) 'Артефакт плохого качества, вызывающий презрение у окружающих’: Рáньше вручну́ю де́лали, такого позо́ру не выпустили бы на во́лю.

(2) 'Душевная мука, мучение, беспокойство'. Ощущение позора связывается в сознании говорящего с внутренними переживаниями: Бbі́ло муче́нье, позо́р. Десятиле́тку поко́нчил с позо́ром-то. Напи́шешь с трудо́м, с больши́м позо́ром. Прима́ть позо́р - 'беспокоиться, переживать за кого-л.': Ско́лько я позо́ру прима́ю. Позору́-то с ни́м.

(3) 'Физические трудности, неудобства'. Тяжесть на душе переносится на физические трудности, необходимость приложения усилий для достижения какой-либо цели: Oй, позо́р зайти́ к овияам, там се́но надо подня́ть наве́рх.

Физические трудности, как правило, связаны с тяжелыми условиями крестьянской жизни на Русском Севере: с тяготами работы на земле, с уходом за крупным рогатым скотом, работой на лесозаготовках и др.

(3.1) Подзначение 'тяжелые условия жизни' реализуется в условиях предложнопадежной сочетаемости - в позо́ре: С ма́лых лет до ста́рости всё в позо́ре. Я ве́к свой, позорли́вая жи́сть, я живу́ в позо́ре.

(3.2) 'Тяжелый труд’: Созвала́ меня́ е́хать на позо́р (тяжелую, непосильную для женщины работу), я́ бы до́ма пожила́.

\section{Позора́ -}

(1) 'Унизительное положение, в котором человек вызывает презрение у окружающих’: В позоре́-то ху́до жить. Ой, позора́ была́, де́вки! Слово позора́ в данном значении часто выступает в роли предиката: Bom позора́-то, вот позора́! Позора́-то! Экспрессивность конструкций с предикатом усиливается местоимениями така́я или кака́я: Нb́́нь тепе́рь така́я позора́! Вот кака́ позора́ была́! Ды'мник не около́чен, и́ш, кака́ позора́.

(1.1) 'Субъект, вызывающий презрение у окружающих': Отойдим промчь, позорам, не позомрься! Така́я позора́ да - пьёт и дерётся. Она́ така́я позора́ (нескладная). Я́то ядрёна, а ты позора́.

(2) 'Душевная мука, мучение, беспокойство'. Степень эмоционального переживания варьируется от сильного мучения до сострадания или легкого беспокойства: Сто́лько го́рюшка да позорь́́ приняла́. У кого́ нет (детей), у того́ и позорь́́ нет.

Значение реализуется в условиях атрибутивной или глагольной сочетаемости:

Чйстая позора́: Чи́стая позора́, как до́лго у нас весна́ идёт. Прилагательное чи́стый здесь имеет значение 'абсолютный'. Атрибут усиливает оценку, заложенную в существительном.

Хвати́mь или приня́ть позори́́ - 'помучиться с кем-л. или чем-л.': Хвати́ла она́ позорьі́, бе́дная. Он боле́л да боле́л, что она́ позорь́ приняла́.

Позора́ в значении душевная мука' становится синонимом таких слов, как го́рюшко, му́ка, беда́: Давно́ я мечта́ла го́рюшко своё вьіписать, свою́ позору́ и му́ку. Позора́, му́ка вели́кая - ра́но выходи́ть (замуж). Во́т мне беда́, позора́ кака́я!

(2.1) ‘Субъект, доставляющий беспокойство’: Отвяжс́сь, позора́, ничего́ у тебя́ не въ́йдет. Денотативная сфера этого значения - дети. Позоро́й называют непослушного ребенка, который доставляет родителям много хлопот: Oй, позора́! C позоро́й не́когда (с детьми). Употребление слова по отношению к ребенку становится универсальной характеристикой любого детеныша: Вот оста́лась позора́ (цыпленок). 
(3) ‘Физические трудности, неудобства' (в предикативной функции): Позора́: накла́ла тяжело́ и не могу́ нести́, вот тебе́ и позора́. Позорю́сь дрова́-то кла́сть: позора́ дрова́-то кла́сть, ничего́ не ви́жу (слепая). Чи́стая позора́ скоту́ (потому что мост далеко).

(3.1) 'Физически слабый, неловкий человек’: Ой, позора́, дава́й я помогу́. Я позо́рюсь, позо́рюсь, а не могу́ подня́ть, муж ска́жет: Ой, позора́, да́й подойму́ са́м.

(3.2) ‘Физическое мучение, боль' (в предикативной функции): Голова́ заболи́т, да u но́чью мне позора́ дак.

(3.2.1) 'Больной орган, приносящий страдание': Я с позоро́й (с больной ногой) хожý. С той, па́ря, позоро́й.

(3.3) 'Тяжелые условия жизни': Е́йна то́же жизнь позора́ одна́ была́. Коро́ву держа́ла, позори́лась, восьмо́й деся́ток живу́, а одна́ позора́. На́ши роди́тели про́жили всё в позоре́ да в му́ке.

(3.4) 'Тяжелый труд’: Не робо́та, а одна́ позора́. Хвати́ло позорь́ (тяжелой работы). Одну́ коро́вку, да и то́ с позоро́й ко́рмим. Ско́лько с е́й де́ла было, позорьи́ (с коровой).

Приня́ть или нести́ позору́ - 'выполнять тяжелую работу': Что' я позоры-то приняла́: и на сплав меня́, и на летний сезо́н. Я ско́лько с до́мом позоры́ несла́... Позора́ в этом значении, как правило, реализуется в контекстах, связанных с работой в колхозе или с ведением домашнего хозяйства: Позора́ - непоси́льная рабо́та. Дак во́m кака́ позора́ в колхо́зе-то.

В переходной зоне между вторым и третьим значениями оказывается семантика позорь́́ в ситуациях, связанных с утратой родственника (супруга, матери и др.). В таких контекстах душевные и физические страдания не дифференцируются: Ше́стеро дете́ú оста́вил на мою́ позору. Позора́ без ма́тери жить. Умерла́, оста́вила меня́ на позору́. Так же описывается уход за больным родственником или за пожилыми родителями: $A$ ведb ба́бушке-то позора́ (с ребенком-инвалидом). То́лько сыновья́м позора́, что с на́ми (приходится возиться).

Итак, в говорах архангельского региона позо́р и позора́ обладают почти полностью совпадающим набором значений. При этом слово позора' более употребительно и развивает больше подзначений (см. таблицу).

Позо́р и позора́ в говорах архангельского региона Pozór and pozorá in Arkhangelsk dialects

\begin{tabular}{|c|c|}
\hline Позомр & Позорам \\
\hline \multicolumn{2}{|c|}{ 'унизительное положение, в котором человек вызывает презрение у окружающих' } \\
\hline $\begin{array}{l}\text { ‘артефакт плохого качества, вызывающий пре- } \\
\text { зрение у окружающих’ }\end{array}$ & $\begin{array}{l}\text { 'субъект, вызывающий презрение у окружаю- } \\
\text { щих' }\end{array}$ \\
\hline \multicolumn{2}{|c|}{ 'душевная мука, мучение, беспокойство’ } \\
\hline- & ‘субъект, доставляющий беспокойство’ \\
\hline \multicolumn{2}{|c|}{ 'физические трудности, неудобства' } \\
\hline & $\begin{array}{l}\text { ‘физически слабый, неловкий человек’ } \\
\text { ‘физическое мучение, боль’ } \\
\text { ‘больной орган, приносящий страдание’ }\end{array}$ \\
\hline \multicolumn{2}{|c|}{ ‘тяжелые условия жизни’ } \\
\hline 'тяже. & Ій труд’ \\
\hline
\end{tabular}


На территории одного населенного пункта или района Архангельской области могут фиксироваться оба слова в нескольких значениях. Например, в Мезенском районе отмечены четыре значения: $B$ шеся́m лет я не бу́ду себя́ на позо́р дава́ть ('посрамление'). Пожале́ла бы ста́рости мои́ да позорь́ ('мучения из-за болезней'). Я уж не зна́ла с йимм позорьі ('забот'). Не жизнь была́, а позора́('му́ка').

\section{3. Срам (страм)}

В говорах архангельского региона существуют два фонемных варианта: срам и страл. Различий в их значении не обнаруживается: У меня́ все тря́nки соро́ки вb́́волочили, сра́м. Всё доста́ли (из заброшенного дома): ка́мни, окна - э́то страм ведь. Далее в качестве заглавного будет использоваться слово страм как собственно диалектное.

\section{Страм -}

(1) 'Нечто неприличное или безнравственное, осуждаемое обществом': По телеви́зору стра́м пока́зыввают, аж тошни́т. Сейча́с всё кака́я-то е́ресь по телеви́зору. Часто употребляется в функции предиката: Шесть сынове́й, а ма́терь так довели́, óŭ стра́м! Mbl (когда) де́вки бьіли: с кавале́ром постои́шь, так э́то уже сра́м. А сейча́с са́ми к ребя́там иду́m, на крова́ть ложа́тся.

Данная семантика слова страм соотносится с позо́ром (в его первом значении) чем-то постыдным с точки зрения общества; с оценкой ситуации, ставшей известной и осуждаемой не самим субъектом действия, а другими людьми: Гря́зно пора́то, стра́м то́лько. Ухудше́нье всё, сра́м-то оди́н. Стра́м ведь, лю́ди ведь при́дут. И больни́иа эта стра́м.

Негативная оценка с повышенной экспрессивностью реализуется в предикативной конструкции что за стра́м: Что́ за стра́м! Ой, каки́ страми́ны,, как одева́ются! (о коротких юбках) Что́ за стра́м-то, говорю́! Я захожу́- никако́й заку́ски не́т, что за стра́м!

Стыд и страм! - экспрессивное выражение, описывающее ситуацию, когда, по мнению говорящего, субъект должен испытывать чувство стыда, а общество - осуждать его поступок. Страм здесь также синонимичен позо́ру: Молодb́e-ти иду́m: пуn го́лый, трусёшки э́ки ма́леньки наде́нут, как пла́вки, и шага́ют по дере́вне, мо́жно сказа́ть, с го́лой жо́пой. Сть́́d и стра́м! Немно́го и ба́ен бь́ло, а тепе́рь кто́ ходит со вща́ми - стьі́ и стра́м!

(2) 'Неловкость, чувство вины за свой поступок': Mы та́к устесня́лися, убежа́ли со срами́. Да срама́-то уш нет, и то́m поте́рян. Во втором значении страм сближается со стьлом.

В сочетании с глаголом в форме инфинитива страм имеет значение 'стыдно, неловко': Сходи́ла да закружи́лась (заблудилась в лесу), да стра́м спра́шивать, ска́жут: ниско́лько ума́ у ба́бки нет. У меня́ милёнок есть, сра́м по у́лице прове́сть: ру'ки-но́ги колесо́м, две́ сосу́льки под носо́м (фольк.).

Таким образом, в одном из своих значений ('нечто безнравственное, осуждаемое обществом') страм является синонимом к позо́ру, а в другом ('неловкость, чувство вины') - к cmыљу́. Наиболее ярко эти семантические схождения проявляются в условиях ограниченной сочетаемости.

\section{Предикативы стыдно, срамно, позорно}

В говорах архангельского региона реакция на свои или чужие поступки, осуждаемые нормами морали и связанные с чувством вины, может описываться с помощью общерусских предикативов сть́́дно, позо́рно и срамно́ (стра́мно). Кроме того, схожей семантикой обладает диалектный предикатив зазо́рно. Рассмотрим подробнее каждое из этих слов. 


\section{1. Стыдно}

Как было упомянуто выше, в русском языке сосуществуют «эмоциональное» (Мне cтылно) и «деонтическое» (Стылно так поступать!) стылно (в терминологии А.Д. Шмелева). В говорах архангельского региона сть́́дно- только эмоциональное.

(1) 'неудобно перед другими': Мнем всегом стыднеме бымло согламсие давамть. Не тамк стылмдо бумдет (занавешивая окно). Предикатив проявляет широкую вариативность в управлении: Пришлам - от людемй-то стымдно. Мне демвочек стымдно, не слыхамли такимх матюкомв. Мне стымдно вам, что у меням немчего поемсть.

Полисемант стылдно развивает в говорах еще два значения, не связанных с чувством вины.

(2) 'страшно за что-н.': Избам стамра, да стымдно за томпленье, томпит, сымрости мномго.

(3) 'трудно': Доромжных людемй (с дороги) напоимть-то стымдно, что ль?

Слово имеет в диалекте словообразовательный вариант стымдко: Камк же стьлмко-то мне!

\section{2. Срамно}

Место деонтического сты́́дно (генерализованное суждение об общей этической норме) в говорах архангельского региона занимает предикатив срамно́ (реже встречается фонемный вариант стра́мно): До двадиати́ годо́в не ро́бить-то срамно́. Ой, како́й необихо́д в избъ́, срамно́ гляде́ть. Вот у ба́бки и това́ру. Стра́мно и носить.

Отметим, что при наличии семантических схождений существительных срам и cmbld, описанных выше, предикатив срамно́ выражает только внешнюю оценку, сближающую его с позором.

\section{3. Позорно}

Позо́рно в значении (1) 'неприемлемо для общества' используется для описания ситуаций, которые осуждаются в коллективе; соотносится с предикативом срамно́, поскольку тоже связано с общей нормой: Родила́ мо́лча, да он уйдёт - вот э́то бьіло позо́рно. А во́т чтоп лю́ди-то не зна́ли. Позо́рно бьі́ло зауго́лка (внебрачного ребенка) принести́. Полови́на молодёжи тако́й о́браз (жизни) веду́m (сходятся-расходятся), ра́ньше было́ позо́рно ведь та́к. Они́ называ́ют: Марийка, Настю́ха, а у на́с - Ма́рья, На́стя. Позо́рнее зови́m, что (чем) у на́с.

(2) 'Неудобно перед другими людьми': Емý позо́рно с посу́дой поро́зной в магази́нто идти́. Ка́к же мне быіть? Мне позо́рно ведь. Хо́дите, дак ва́м не позо́рно в штана́х. Синонимично эмоциональному сть́́дно (кому-то позо́рно- кому-то стьі́дно).

(3) 'Тяжело, плохо’: Алёна уила́ от мужика́, позо́рно бы́ло одно́й. Позо́рно - э́то тяжелó. Вот я́ оста́лась от (без) ма́тери, дак напозори́лась. Эта семантика предикатива идет от диалектных значений позо́ра и позорй́, связанных с мучением и тяжелым трудом.

\section{4. Зазорно}

Диалектный предикатив зазо́рно так же совмещает в себе эмоциональное и деонтическое значения, как и слово позо́рно.

(1) 'Позорно, неприемлемо для общества': Не зазо́рно. Ничего́ в ней тако́го зазо́рного нет, то́лько пьёт.

(2) ‘Стыдно перед другими людьми': Сто́ль мне зазо́рно да сто́ль мне позо́рно бы́лло (что дочь выходит замуж за пьяницу). В этом контексте, очевидно, слово зазо́рно обозначает внутреннее чувство, а позо́рно - внешнюю оценку.

Предикатив зазо́рно в говорах развивает еще одно значение, не связанное с чувством вины.

(3) ‘Завидно’: Мне́-то зазо́рно: у тебя́ есть, а у меня́ нет. 
Таким образом, предикативы сть́́дно, позо́рно, срамно́ и зазо́рно, некоторыми своими значениями образуют особую зону синонимии. Их взаимосвязь представлена на рисунке.

В «эмоциональном» значении синонимами становятся слова позо́рно, сты́́dно и зазо́рно, в «деонтическом»- позо́рно, зазо́рно и срамно́. Все рассмотренные предикативы, кроме слова срамно́, являются полисемантами, развивая и другие значения, не связанные с чувством вины и безнравственным поведением.

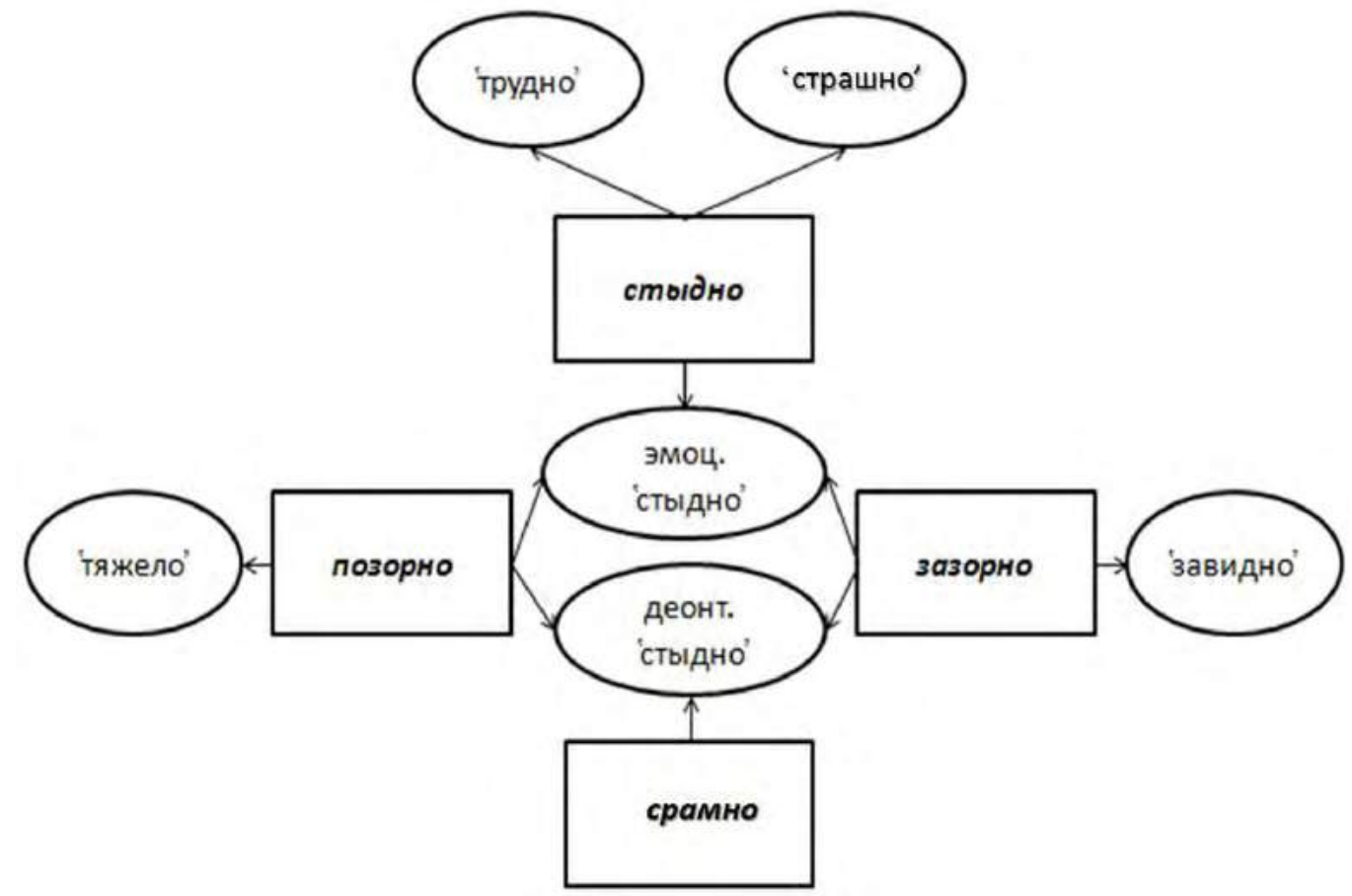

Рис. Предикативы сти́́дно, позо́рно, зазо́рно, срамно́ в исследуемых говорах

Fig. Predicatives stýdno, pozórno, zazórno, sramnó in researched dialects

\section{Выводы}

В результате проведенного исследования в говорах архангельского региона обнаружилось более четкое, чем в литературном языке, разграничение семантики рассматриваемых общерусских слов. Cmыл - обозначение индивидуального чувства, страм - внешняя негативная оценка, в кодифицированном литературном языке выражаемая словом позор. В говорах же семантика позо́ра и позорь́́ преимущественно связана с мучением и тяжелыми условиями жизнедеятельности, хотя значение 'унизительное положение, бесчестье' здесь также отмечено. Полисемия всех этих слов позволяет им на уровне дериватов становиться в одном из своих значений полными синонимами, что демонстрируют описанные выше предикативы сть́́дно, позо́рно и срамно́ (а также диал. зазо́рно).

\section{Список источников}

1. Архангельский областной словарь. 1980. Вып. 1 (А - Бережок). Под ред. О.Г. Гецовой. М., Изд-во Моск. ун-та, 168 с.

2. Словарь русского языка (MAC). В 4-х т.Под ред. А.П. Евгеньевой. URL: http://febweb.ru/feb/mas/mas-abc/default.asp (дата обращения: 10.02.2020).

3. Русский ассоциативный словарь. Составители: Ю. Н. Караулов, Г. А. Черкасова, Н. В. Уфимцева и др.: В 2 т. М., 2002. 
4. Словарь русских народных говоров. 1970. Под ред. Ф.П. Сороколетова и Ф.П. Филина. 6: Выросток - Гон. Л., Наука, 360 с.

5. Словарь русских народных говоров. 2008. Под ред. Ф.П. Сороколетова и О.Д. Кузнецовой. 42: Стриж - Сухловина. СПб., Наука, 330 с.

6. Словарь русского языка XI-XVII вв. 2008. Под ред. В.Б. Крысько. Вып. 28: Старичекъ Сулебный. М.: Наука, 303 с.

7. Фасмер М. 2009. Этимологический словарь русского языка. В 4 т. 3: Муза - Сят. М., Астрель -АСТ, 830 с.

8. Черных П.Я. 1999. Историко-этимологический словарь современного русского языка.

9. В 2 т-х. т. 2: Панцирь - Ящур. М., Русский язык, 560 с.

\section{Список литературы}

1. Арутюнова Н.Д. 1997. О стыде и стуже. Вопросыязыкознания, 2: 59-70.

2. Арутюнова Н.Д. 1999. Язык и мир человека. М., Языки русской культуры, 911 с.

3. Арутюнова Н.Д. 2000. О стыде и совести. В кн.: Логический анализ языка: Языки этики. М., Наука: 54-78.

4. Вендина Т.И. 1998. Русская языковая картина мира сквозь призму словообразования (макрокосм). М., Индрик, 240 с.

5. Виноградов В.В. 1941. Лексикологические заметки. Ученые записки Московского государственного педагогического дефектологического института, 1: 18-19.

6. Ермакова О.П. 1999. Концепты СОВЕСТЬ и СТЫД по данным языка. В кн.: Русский язык в контексте культуры. Екатеринбург: 54-59.

7. Зализняк А.А., Левонтина И.Б., Шмелев А.Д. 2012. Константы и переменные русской языковой картины мира. М., Языки славянских культур, 693 с.

8. Колесов В.В. 2004. Язык и ментальность. СПб., Петербургское Востоковедение, 238 с.

9. Рукавишникова М.В. 2009. Совесть как многогранный феномен. Этимологический и лексический анализ. Вестник Нижегородского университета им. Н.И. Лобачевского - Bulletin of the Lobachevsky University of Nizhny Novgorod, 2(14): 121-126.

10. Толстая С.М. 2008. Пространство слова. Лексическая семантика в общеславянской перспективе. М., Индрик, 528 с.

11. Шмелев А.Д. 2002. Русская языковая модель мира. Материалы к словарю. М., Языки славянской культуры, 224 с.

12. Языковая картина мира и системная лексикография. 2006. Под ред. Ю.Д. Апресяна. М.: Языки славянских культур, 912 с.

\section{References}

1. Arutyunova N.D. 1997. O styde i stuzhe [About shame and cold]. Voprosy yazykoznaniya Questions of linguistics, 2: 59-70.

2. Arutyunova N.D. 1999. YAzyk i mir cheloveka [Language and the world of man]. Moscow, Publ. Yazyki russkoj kul'tury, $911 \mathrm{p}$.

3. Arutyunova N.D. 2000. O styde i sovesti [About shame and conscience]. In: Logicheskij analiz yazyka: Yazyki ehtiki [Logical analysis of language: languages of ethics]. Moscow, Publ. Nauka: 54-78.

4. Vendina T.I. 1998. Russkaya yazykovaya kartina mira skvoz' prizmu slovoobrazovaniya (makrokosm) [Russian language picture of the world through the prism of word formation (macrocosm)]. Moscow, Publ. Indrik, 240 p.

5. Vinogradov V.V. 1941. Leksikologicheskie zametki [Lexicological notes]. Uchyonyje zapiski Moskovskogo gosudarstvennogo pedagogicheskogo defektologicheskogo institute - Scientific notes of the Moscow state pedagogical defectological Institute, 1: 18-19.

6. Ermakova O.P. 1999. Kontsepty SOVEST' i STYD po dannym yazyka [CONSCIENCE and SHAME concepts according to language]. In: Russkij yazyk v kontekste kul'tury [Russian language in the context of culture]. Sbornik statey. Ekaterinburg: 54-59. 
7. Zaliznyak A. A., Levontina I.B., SHmelev A.D. 2012. Konstanty i peremennye russkoj yazykovoj kartiny mira [Constants and variables of the Russian language picture of the world]. Moscow, Publ. Yazyki slavyanskikh kul'tur, 693 p.

8. Kolesov V.V. 2004. Yazyk i mental'nost' [Language and mentality]. Saint-Petersburg, Publ. Peterburgskoe Vostokovedenie, $238 \mathrm{p}$.

9. Rukavishnikova M.V. 2009. The phenomenon of conscience fenomenological and lexicological analisis. Vestnik of Lobachevsky State University of Nizhni Novgorod, 2(14): 121-126.

10. Tolstaya S.M. 2008. Prostranstvo slova. Leksicheskaya semantika v obshheslavyanskoj perspective [The space of the word. Lexical semantics in the Slavic perspective]. Moscow, Publ. Indrik, $528 \mathrm{p}$.

11. SHmelev A.D. 2002. Russkaya yazykovaya model' mira. Materialy k slovaryu [Russian language model of the world. Dictionary Materials]. Moscow, Publ.YAzyki slavyanskoj kul'tury, 224 p.

12. YAzykovaya kartina mira i sistemnaya leksikografiya [Language picture of the world and systemic lexicography]. 2006. Ed. Yu.D. Apresyan. Moscow, Publ. YAzyki slavyanskikh kul'tur, 912 p.

\section{ИНФОРМАЦИЯ ОБ АВТОРЕ}

Яковлева (Редько) Наталья Александровна, младший научный сотрудник, соискатель ученой степени кандидата филологических наук на кафедре русского языка филологического факультета Московского государственного университета имени М.В. Ломоносова, Военная академия Генерального штаба ВС РФ, г. Москва, Россия

\section{INFORMATION ABOUT THE AUTHOR}

Natalya A. Yakovleva (Redko), Junior Researcher, Candidate of Philology degree at the Russian Language Department of the Philology Faculty of Moscow State University named after M.V. Lomonosov, Military Academy of the General Staff of the RF Armed Forces, Moscow, Russia 